Web Site: https://jmed.utq.edu.iq

Email:utjmed@utq.edu.iq

ISSN (Print):1992-92 18, ISSN (Online):1992-92 18

DOI: https://doi.org/10.32792/utq/utjmed/18/2/6

\title{
Hemoglobinopathies According To Blood Groups In Thi-Qar Governorate
}

\author{
Assistant lecturer Rawaa Kamel Abd ( Master Community Health Tech . Kut Technical \\ Institute ) \\ Raawaa9922@Gmail .com \\ Assistant lecturer Qassim Jawell Odah ( Master Adult Nursing. Kut Technical Institute ) \\ Qassimalabody@yahoo.com \\ Assistant lecturer Sameeha Naser Abd( Master Community Health Tech. Kut Technical \\ Institute ) \\ Nassers34@yahoo.com
}

\section{Abstract:}

The hemoglobinopathies are a group of disorders that acquired through families in which there is abnormal creation or structure of the hemoglobin molecule, which cause a considerable public health problem. The carriers of $\mathrm{Hb}$ diseases worldwide are estimated to be 269 million with about 400,000 births a year. The birth of effected child, consequently, places extensive physical, physiological and fiscal burden, not only on the affected child and its family, but also on the society and the nation at large.

Methodology: In this cross- sectional study 601 patients with hemoglobinopathies (317 males and 284 females), Whose age ranged from months to $\geq 40$ years. They were attending genetic blood disease center at Al- Habobi hospital in Thi-Qar governorate during the data collection period ( $1^{\text {st }}$ March to 31 May 2016).

\section{$\underline{\text { Results: }}$}

Thalassemia has high prevalence than other hemoblobinopathies (76.53) and majority of cases was blood group O. The highly percentage of cases was at age $\leq 10$ years $(54.08)$ followed by 21-30 years was (34.44), highly percentage of cases was in urban (60.90).

Recommendations: Adequate and suitable therapeutic and preventive measures should be taken to diminish birth of effected children such as health education of individuals about importance of premarital screening program for all couple to identify gen carrier individual of hemoglobinopathies.

Key words: Hemoglobinopathies, Thalassemia, Sickle cell disease 


\section{Introduction:}

The hemoglobinopathies are among the most widely recognized monogenic disease (1). Caused by gene mutations ${ }^{(2)}$. In addition, $\mathrm{ABO}$ and $\mathrm{Rh}$ blood grouping are likewise important factor in transfusion and medicine and to reduce newborn hemolytic disease ${ }^{(3)}$. Hemoglobinopathies status that influence kind and amount of hemoglobin (4). Hemoglobin is a tetramer protein made out of 2 sets of globin chains working in conjunction with 4 heme groups to transport oxygen in the blood ${ }^{(5)}$.

The umbrella term "hemoglobinopathy comprise all hereditary hemoglobin disorders ${ }^{(6)}$. This may be either causing qualitative abnormalities as Sickle cell disease or causing quantitative abnormalities as Thalassemias ${ }^{(7)}$. Sickle cell disease refers to a collection of autosomal recessive diseases including sickle cell anemia $(\mathrm{Hb}$ $\mathrm{SS}), \mathrm{Hb} \mathrm{SC}$, and sickle cell/ $\beta$-Thalassemia ${ }^{(8,9)}$. This genetic variation be due to substitution of amino acid valine for the glutamic acid at the $6^{\text {th }}$ position of beta chain of hemoglobin ${ }^{(10)}$. The pathological features of Sickle cell disease due to the shortened lifetime of the sickled blood cells (16-20 days in contrast to a lifetime of 120 days in normal red cells) (11)

Thalassemia is a complex heterogeneous group of diseases (12) ranging from serious anemia to clinically asymptomatic individuals ${ }^{(13)}$. It occurs due to diminution generation of hemoglobin. There are two fundamental sorts of thalassemia, Alpha thalassemia occurs when the imperfection occur in alpha globin gene while Beta thalassemia happened when the defect occur in beta globin gene ${ }^{(14)}$. $\beta$-Thalassemia is characterized by the reduced or absent production of $\beta$-globin chains in the hemoglobin molecule leading to an excess of $\alpha$-globin chains $^{(15)}$. $\alpha$-Thalassemia is characterized by the reduced or absent synthesis of $\alpha$-globin chains ${ }^{(16)}$. This study was conducted to investigate prevalence of hemoglobinopathies related to blood groups in Thi-qar governorate.

\section{Subjects and Methods:}

Ethical clearance: Approval to run the study was taken from genetic blood disease center and Verbal Permission from the studied group was taken.

Study design: Our study used a cross sectional design to achieve the aim of study.

Setting: present study was conducted at specialized center for genetic blood disease at Al- Habobi hospital in Thi-Qar governorate.

Study period: The time of data collection, took 3 months extended from $1^{\text {st }}$ March to 31 May 2016.

Study sample: include 600 patients was diagnosed to have genetic blood diseases attending genetic blood disease center.

Inclusion criteria: all patients with hemoglobinopathies( all type of sickle cell disease \& thalassemia) 
DOI: https://doi.org/10.32792/utq/utjmed/18/2/6

Exclusion criteria: patients with other genetic blood disease as hemophilia and bone marrow failure.

Data collection: Data collected by use special questionnaire constructed by the researchers. The patient sheet designed to encompass demographic characteristic of patients as ( age, gender, socioeconomic status). Other information for this study was taken from patient chart as (blood group, diagnosis, splenoctomy).
Statistical Analysis: Descriptive statistics were computed for sex, age and other variable. Tables of frequencies and percentage for independent variables were calculated. Chi square and ANOVA tests was used for testing relationships on categorical variables by using Statistical Package for Social Science (SPSS) version 20 .

Results: The descriptive results of cases according to age and gender and residence are shown below. The following results consisted of 601 patients Age ranged from months to $\geq 40$ years ( 317 males and 284 females). The highly percentage of cases was at $\leq 10$ years (54.08) followed by 21-30 years was (34.44). Regarding residence, highly percentage of cases was urban (60.90). 
Thi-Qar Medical Journal (TQMJ):Vol.(18),No.(2),2019

Web Site: https://jmed.utq.edu.iq

Email:utjmed@utq.edu.iq

ISSN (Print):1992-92 18, ISSN (Online):1992-92 18

DOI: https://doi.org/10.32792/utq/utjmed/18/2/6

Table (1) Distribution of cases according to age and gender and residence.

\begin{tabular}{|c|c|c|c|}
\hline Variables & & No. & $\%$ \\
\hline \multirow[t]{5}{*}{ Age (years) } & $\leq 10$ & rro & $0 \leqslant, \cdot \Lambda$ \\
\hline & $11-20$ & $r \cdot V$ & $\Gamma \varepsilon, \varepsilon \varepsilon$ \\
\hline & r -30 & 0 . & A, \\
\hline & 4-40 & 10 & r,o. \\
\hline & $\geq 40$ & $\varepsilon$ &., $7 V$ \\
\hline Mean $\pm S D$ & $11.36 \pm 7.988$ & & \\
\hline \multirow[t]{2}{*}{ Gender } & Male & H IV & or, $V \varepsilon$ \\
\hline & Female & r^乏 & $\varepsilon V, Y\}$ \\
\hline \multirow[t]{2}{*}{ Residence } & Urban & rq & $7 \cdot, 9$ \\
\hline & Rural & ro & rq, 1. \\
\hline
\end{tabular}

Table (2) display that male have thalassemia more than female represented by (53.14) while highly percentage of female have sickle cell disease compare with male where the percentage was (51.77)

Table 2: relationship between hemoglobinopathies and gender

\begin{tabular}{llllll}
\hline Gender & \multicolumn{2}{l}{ Thalassemia } & \multicolumn{2}{c}{ Sickle cell } & p-value \\
\cline { 2 - 6 } & No. & $\%$ & No. & $\%$ & 0.219 \\
Male & 249 & 54.14 & 68 & 48.22 & \\
Female & 211 & 45.86 & 73 & 51.77 & \\
All & 460 & & & & \\
\hline
\end{tabular}

Chi- square (1.629) 
Thi-Qar Medical Journal (TQMJ):Vol.(18),No.(2),2019

Web Site: https://jmed.utq.edu.iq

Email:utjmed@utq.edu.iq

ISSN (Print):1992-92 18, ISSN (Online):1992-92 18

DOI: https://doi.org/10.32792/utq/utjmed/18/2/6

Table 3 showed that high percentage of cases was female have thalassemia at blood group $\mathrm{O}$ and $\mathrm{A}$ but in other blood groups the high percentage found in male than female, while in sickle cell disease high percentage represented male than female at all blood group .

Table (3) relationship between blood group and type of disease

\begin{tabular}{|c|c|c|c|c|c|c|c|c|c|c|c|c|}
\hline \multirow{3}{*}{$\begin{array}{l}\text { Blood } \\
\text { group }\end{array}$} & \multicolumn{6}{|c|}{ Thalassemia } & \multicolumn{6}{|c|}{ Sickle cell disease } \\
\hline & \multicolumn{2}{|c|}{ Male } & \multicolumn{2}{|c|}{ Female } & \multicolumn{2}{|c|}{ Total } & \multicolumn{2}{|c|}{ Male } & \multicolumn{2}{|c|}{ Female } & \multicolumn{2}{|c|}{ Total } \\
\hline & $\begin{array}{l}\text { No } \\
\text {. }\end{array}$ & $\%$ & No. & $\%$ & No. & $\%$ & No. & $\%$ & No. & $\%$ & No. & $\%$ \\
\hline $\mathbf{O}$ & 23 & 33.82 & 34 & 46.43 & 57 & 40.43 & 88 & 35.34 & 61 & 28.91 & 149 & 32.39 \\
\hline $\mathbf{A}$ & 17 & 25.00 & 21 & 28.88 & 38 & 26.95 & 80 & 32.13 & 67 & 31.75 & 147 & 31.96 \\
\hline B & 18 & 26.47 & 12 & 16.44 & 30 & 21.28 & 55 & 22.09 & 62 & 29.38 & 117 & 25.43 \\
\hline $\mathbf{A B}$ & 10 & 14.71 & 6 & 8.22 & 16 & 11.35 & 26 & 10.44 & 21 & 9.95 & 47 & 10.22 \\
\hline Total & 68 & 100 & 73 & 100 & 141 & 100 & 249 & 100 & 211 & 100 & 460 & 100 \\
\hline
\end{tabular}

Table 4 illustrate that total 601 patients had hemoglobinopathies, majority of B- thalassemia patient was in blood group type B represented by (68.03) thalassemia major and (10.20) thalassemia intermediate while sickle cell disease has high percentage in blood group $\mathrm{O}$ more than other blood groups. 
Thi-Qar Medical Journal (TQMJ):Vol.(18),No.(2),2019

Web Site: https://jmed.utq.edu.iq

Email:utjmed@utq.edu.iq

ISSN (Print):1992-92 18, ISSN (Online):1992-92 18

DOI: https://doi.org/10.32792/utq/utjmed/18/2/6

Table 4: Spectrum of hemoglobinopathies according to blood groups

\begin{tabular}{|c|c|c|c|c|c|c|c|c|}
\hline \multirow{2}{*}{ type of disease } & \multicolumn{2}{|l|}{$\mathbf{O}$} & \multicolumn{2}{|l|}{$\mathbf{A}$} & \multicolumn{2}{|l|}{ B } & \multicolumn{2}{|l|}{$\mathbf{A B}$} \\
\hline & No. & $\%$ & No. & $\%$ & No. & $\%$ & No. & $\%$ \\
\hline$\beta$-thalassemia major & 138 & 66.99 & 135 & 72.97 & 100 & 68.03 & 44 & 69.84 \\
\hline$\beta$-thalassemia intermediat & 11 & 5.34 & 12 & 6.49 & 15 & 10.20 & 4 & 6.35 \\
\hline Sickle cell disease $(\mathrm{HbS})$ & 44 & 21.36 & 29 & 15.68 & 24 & 16.33 & 11 & 17.46 \\
\hline Sickle cell trait & 5 & 2.43 & 4 & 2.16 & 3 & 2.04 & 4 & 6.35 \\
\hline Sickle/beta thalassemia & 5 & 2.43 & 4 & 2.16 & 1 & 0.68 & 0 & 0.00 \\
\hline Hc thalassemia & 3 & 1.46 & 1 & 0.54 & 2 & 1.36 & 0 & 0.00 \\
\hline Other & 0 & 0.00 & 0 & 0.00 & 2 & 1.36 & 0 & 0.00 \\
\hline Total & 206 & 100 & 185 & 100 & 147 & 100 & 63 & 100 \\
\hline
\end{tabular}

P-value $=0.262$

\section{Discussion:}

Hemoglobinopathies are a group of inherited disorders of hemoglobin. They affect $4.5 \%$ of the world population. The current study aims to explore the prevalence of hemoglobinopathies in Thi- qar governorate.

The descriptive results of cases according to age and gender and residence are shown in table (1). These results consisted of 601 patients Age ranged from months to $\geq 40$ years (317 males and 284 females). The highly percentage of cases was at $\leq 10$ years (54.08) followed by 21-30 years was (34.44) These findings agreed with what has been stated by Karthika M1, et al. 2015 in Manipur, who found that highly percentage of cases was at 0-18 years and in male than female $^{(14)}$.

Regarding residence, highly percentage of cases was urban (60.90) this finding was opposite to the study Bikash Mondal, et al, 2012 in India ${ }^{(3)}$.

The present study also display that male have thalassemia more than female represented by (53.14) while highly percentage of female have sickle cell disease compare with male where the percentage was (51.77) and this agreed with what had been reported by Balgir RS,2005, India ${ }^{(17)}$.

The current study reveal that high percentage of cases was female have thalassemia at blood group $\mathrm{O}$ and $\mathrm{A}$ but in other blood groups the high percentage 
Web Site: https://jmed.utq.edu.iq

ISSN (Print):1992-92 18, ISSN (Online):1992-92 18

DOI: https://doi.org/10.32792/utq/utjmed/18/2/6

found in male than female, while in sickle

cell disease high percentage represented male than female at all blood group This result match with Bikash Mondal, et al, 2012 in India who stated that the gene frequencies with respect to $\mathrm{ABO}$ can be shown as $\mathrm{O}>\mathrm{B}>\mathrm{A}>\mathrm{AB}^{(3)}$.

In this study, we found out majority of cases was B- thalassemia patient represented by (68.03) thalassemia major and (10.20) thalassemia intermediate followed by sickle cell disease These results supported by Shaista Shabbir1, et al. 2016 in Pakistan $^{(18)}$.

\section{Conclusions:}

Remarkable spread of hemoglobinopathies from this study we conclude. And thalassemia has more

\section{References}

Email:utjmed@utq.edu.iq

prevalence than other hemoblobinopathies also male more susceptible than female The reason for this susceptibility for abnormal $\beta$ thalassemia is unknown, and finally majority of cases was blood group $\mathrm{O}$.

\section{Recommendations:}

Adequate and suitable therapeutic and preventive measures should be taken to diminish birth of effected children such as health education of individuals about importance of premarital screening program for all couple to identify gen carrier individual of hemoglobinopathies. For future studies, we suggest a large sample in different governorates.

1. Maria D, Fernando F. The genetics of blood disorders: hereditary hemoglobinopathies. Jornal de Pediatria. 2008 - Vol. 84, Issue. 4.

2. Chiyome L, Thalassemias and Other Hemoglobinopathies Protocol. Hawai'i State Department of Health, Children with Special Health Needs Branch, Genetics Program. 2008

3. Bikash M, Soumyajit M, Biplab K et al. Prevalence of hemoglobinopathy, ABO and rhesus blood groups in rural areas of West Bengal, India. J Res Med Sci. 2012 , Vol 17 No (8):P 772-776.

4. Holton, J.B., Walter, J.H., Tyfield, L.A, et al. The Hemoglobinopathies. The Metabolic and Molecular Bases of Inherited Disease, 8th ed. McGraw-Hill, New York. 2001. 
Web Site: https://jmed.utq.edu.iq

ISSN (Print):1992-92 18, ISSN (Online):1992-92 18

DOI: https://doi.org/10.32792/utq/utjmed/18/2/6

5. Eric D. Jacobsen, Hemoglobinopathies. www.turner-white.com H Hematology, 2010 Volume 5, Part 3.

6. Elisabeth K. Hemoglobinopathies Clinical Manifestations, Diagnosis, and Treatment, Deutsches Ärzteblatt International Dtsch Arztebl Int 2011; Vol 108 , P:31-32.

7. Ambroise W. Hemoglobinopathies: molecular genetics and prenatal diagnosis, 2007; Vol $27 ; \mathrm{p} 982$.

8. Tan, Sickle cell trait and small for gestational age babies: Is there a link? Journal of Obstetrics and Gynecology 2008. Vol 28, No 3, P:298-300.

9. Kaur M, Dangi C and Singh M. An Overview on Sickle Cell Disease Profile, Asian J Pharm Clin Res, 2013. Vol 6, Suppl 1, P: 25-37.

10. Lorna B, Claire C, Bernard D. Standards for the Clinical Care of Adults with Sickle Cell Disease in the UK, Sickle Cell Society 2008.

11. Standards of Care Guidelines for Thalassemia, 2012.

12. Renzo G and Raffaella O. "Beta-thalassemia". Galanello and Origa Orphanet Journal of Rare Diseases 2010.

13. Sathi T, Vishnu D, Siva G an Overview on Thalassemia. International Research Journal for Inventions in Pharmaceutical Sciences. 2013;Vol (1);Issue 1:p1-12.

14. Karthika M, Ksh G, Deisha B. Prevalence of Hemoglobinopathies in Manipur. IOSR Journal of Dental and Medical Sciences, 2012. Volume 14, Issue 8, P17-20 
Thi-Qar Medical Journal (TQMJ):Vol.(18),No.(2),2019

Web Site: https://jmed.utq.edu.iq

ISSN (Print):1992-92 18, ISSN (Online):1992-92 18

Email:utjmed@utq.edu.iq

DOI: https://doi.org/10.32792/utq/utjmed/18/2/6

15. . Saovaros S, Orapan S.Genomic Study in $\beta$-Thalassemia, Advances in the Study of Genetic Disorders, Dr. Kenji Ikehara (Ed.). In Tech open science. 2011;p149-168.

16. Urkude V, Mishra A. RNA Silencing: An Approach for the Treatment of $\beta$-Thalassemia. J Cell Science \& Therapy .2012; Volume (3) ; Issue 7:P 2-4.

17. Balgir RS. Spectrum of Hemoglobinopathies in the state of Orissa, India: A Ten years cohort study. J Assoc Physicians India. 2005.

18. Shaista Muhammad N, Abdul S. Type and frequency of hemoglobinopathies, diagnosed in the area of Karachi, in Pakistan, Cogent Medicine 2016. 
Web Site: https://jmed.utq.edu.iq

Email:utjmed@utq.edu.iq

ISSN (Print):1992-92 18, ISSN (Online):1992-92 18

DOI: https://doi.org/10.32792/utq/utjmed/18/2/6

\section{اعتلال الهيموغلوبين حسب فصائل الدم في محافظة ذي قار}

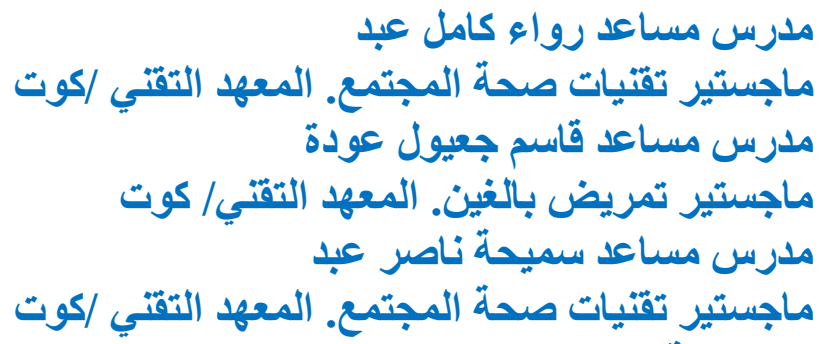

الخلاصة: إن اعتلال الهيمو غلوبين هو مجموعة من الاضطر ابات التي تكتسب من العائلة التي يوجد فيها خلل غير طبيعي في تكوين او تركيب جزيء الهيموجلوبين الذي بسبب مشكلة

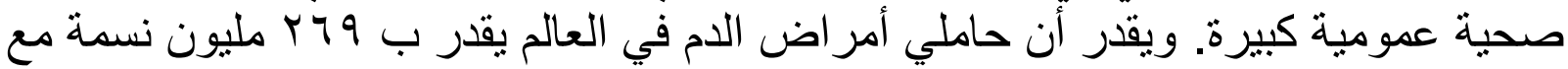

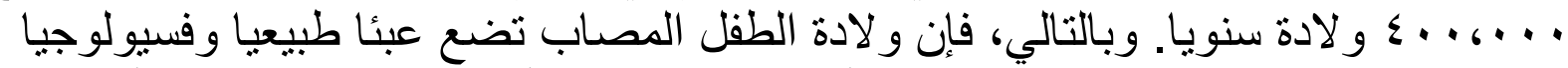
و ماليا كبير ا، ليس على الطفل المتضرر و أسرته فحسب، بل أبضا على المدة المجتمع و الأمة عموما. أجريت هذه الدراسة للتحقيق في انتشار اعتلال الهيموجلوبين المرتبط بمجمو عات الدم في محافظة ذي قار

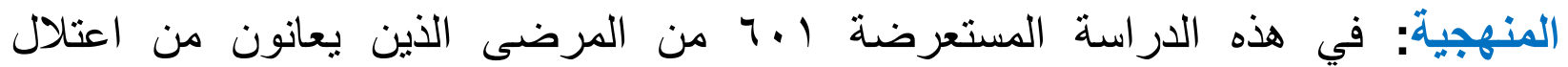

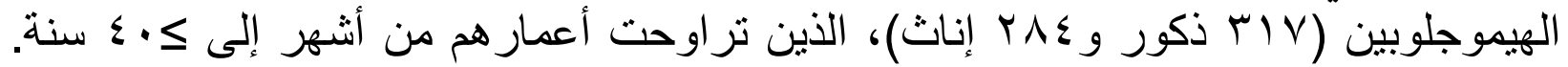

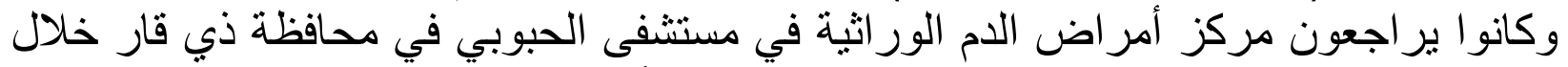

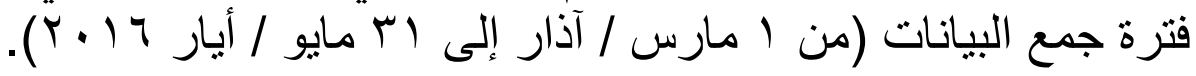

النتائج: الثنلاسيميا أكثر انتشار من بين امراض اعتلال الهيموجلوبين الأخرى حيث كانت إته النسبة المئوية (ب,0 (V ) وكانت غالبية الحالات فصيلة الدم O. النسبة المئوية عالية للحالات

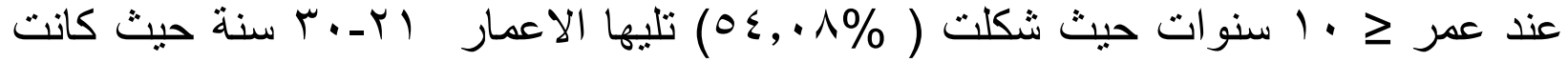

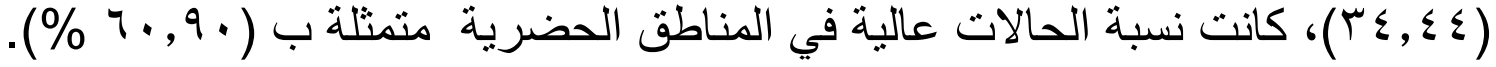
الثّوصيات: برنامج فحص شامل للمقبلين على الزواج لتحديد الافر اد الحاملين لجينات اعتلال الهيموجلوبين، حيث يسهة في للحد من و لادة اطفال مصسابين مما يساعد في اتخاذ تدابير علاجية ووقائية كافية و مناسبة. 